\title{
Comparison of Five Fungicides on Development of Root, Crown, and Fruit Rot of Chile Pepper and Recovery of Phytophthora capsici from Soil
}

\author{
M. E. Matheron, Extension Plant Pathologist and Research Scientist, and M. Porchas, Research Specialist, \\ University of Arizona, Yuma Agricultural Center, Yuma, 85364
}

\begin{abstract}
Matheron, M. E., and Porchas, M. 2000. Comparison of five fungicides on development of root, crown, and fruit rot of chile pepper and recovery of Phytophthora capsici from soil. Plant Dis. 84:1038-1043.

The activity of five fungicides, azoxystrobin, dimethomorph, fluazinam, fosetyl-Al, and metalaxyl (subsequently replaced with mefenoxam by the manufacturer), was compared for effects on the development of root, crown, and fruit rot of chile pepper and on recovery of Phytophthora capsici from naturally infested soil. When inoculated with zoospores, plants survived longer and shoot and root fresh weights were greater for plants drenched with metalaxyl at 10 $\mu \mathrm{g} / \mathrm{ml}$ than for plants treated with the same rate of azoxystrobin or dimethomorph. At $100 \mu \mathrm{g} / \mathrm{ml}$, the duration of plant survival was greater for dimethomorph and fluazinam than for azoxystrobin; however, shoot and root growth did not differ. In soil naturally infested with $P$. capsici, survival and growth of shoots and roots for plants treated with dimethomorph at $100 \mu \mathrm{g} / \mathrm{ml}$ were greater than for those treated with the same rate of azoxystrobin or fluazinam. The most effective compounds for inhibition of lesion development on stems and fruit were mefenoxam at $1,200 \mu \mathrm{g} / \mathrm{ml}$ and dimethomorph at $480 \mu \mathrm{g} / \mathrm{ml}$. Recovery of $P$. capsici from soil treated with each of the five tested compounds was significantly less than that recorded for soil not receiving a fungicide. The potential and relative value of azoxystrobin, dimethomorph, fosetyl-Al, and fluazinam as chemical management tools for Phytophthora blight on chile pepper, in addition to metalaxyl (replaced with mefenoxam), has been demonstrated.
\end{abstract}

Phytophthora blight of peppers (Capsicum annuum), caused by the oomycete pathogen Phytophthora capsici, occurs in most regions where this crop is grown (19). Chile pepper production in Arizona (11) and New Mexico (1) can be affected significantly by the destructive effects of $P$. capsici. In Arizona, the root and crown rot phase of the disease appears on plants early in the growing season in areas where soil remains saturated after irrigation. Subsequent irrigations encourage further disease development. As the crop canopy covers the rows within the field, the foliar blight phase of the disease may occur with the onset of the summer rainy season in July and August. During this time, stems, leaves, and developing pepper fruits may be attacked by the pathogen.

The efficacy of the systemic fungicide metalaxyl (trade name Ridomil; Novartis Crop Protection, Greensboro, NC) for control of Phytophthora blight on pepper was documented during the 1980 s and early 1990 s $(9,17,21,22)$. Recently, the manufacturer replaced metalaxyl with mefenoxam (trade name Ridomil Gold). Me-

Corresponding author: M. E. Matheron

E-mail: matheron@ag.arizona.edu

Accepted for publication 6 June 2000.

Publication no. D-2000-0724-02R

(C) 2000 The American Phytopathological Society fenoxam is the active component within the fungicide metalaxyl and is applied in a manner similar to that for metalaxyl, only at lower rates of manufactured product. Several other fungicides, including azoxystrobin (Quadris; Zeneca Ag Products, Wilmington, DE; 7), dimethomorph (Acrobat; American Cyanamid Co., Princeton, NJ; 3,6,10), fluazinam (Zeneca Ag Products, Wilmington, DE; 5,24), and fosetylAl (Aliette; Aventis Crop Science, Research Triangle Park, NC; 4,15,23), have an effect on some species of Phytophthora and the diseases they cause on crops other than pepper. The effect of these compounds on the growth, sporulation, and zoospore cyst germination of $P$. capsici has been determined (14). The objective of this study was to compare the effects of a soil drench treatment with azoxystrobin, dimethomorph, fluazinam, fosetyl-Al, mefenoxam, or metalaxyl on development of root and crown rot on chile pepper and recovery of $P$. capsici from naturally infested soil. Also examined was the effect of stem and fruit treatment with each fungicide on subsequent growth of fungal lesions after inoculation.

\section{MATERIALS AND METHODS}

Fungi and fungicides. Except for studies involving soil naturally infested with $P$. capsici, one isolate (MIS-6C) of the pathogen was used in all investigations. This isolate originated from a chile pepper plant in a commercial field in southeastern Ari- zona. The following formulations of tested fungicides were used in these studies: azoxystrobin (Quadris 80WG), dimethomorph (Acrobat 50WP), fluazinam (Fluazinam 50WP), fosetyl-Al (Aliette 80WDG), mefenoxam (Ridomil Gold 44WP), and metalaxyl (Ridomil 2E).

Disease development: inoculation with zoospores. In July 1994, seeds of chile pepper (cv. AZ 20; Curry Seed Co., Pearce, AZ) were sown and germinated in vermiculite. Seedlings were transplanted at the three-leaf stage into sterile potting mix (peat:vermiculite 60:40 by volume) in plastic pots $(10 \mathrm{~cm}$ in diameter by $10 \mathrm{~cm}$ deep) and grown in the greenhouse. When plants were 3 months old, the potting mix within each container was drenched with $300 \mathrm{ml}$ of a solution containing the following concentrations of test fungicides: azoxystrobin or dimethomorph at 10, 25, $50,100,250,500$, and $1,000 \mu \mathrm{g} / \mathrm{ml}$; fluazinam at 50,100, 250, 500 and $1,000 \mu \mathrm{g} / \mathrm{ml}$; fosetyl-Al at 250, 500, 1,000, and 3,000 $\mu \mathrm{g} / \mathrm{ml}$; and metalaxyl at 10,25 , and 50 $\mu \mathrm{g} / \mathrm{ml}$. Five replicate plants were treated with each concentration of each fungicide. Control plants were treated with water only.

Zoospores of $P$. capsici were produced by previously described procedures (11). Briefly, an isolate of the pathogen (MIS6C) was grown on V8 juice agar (V8A) at $24^{\circ} \mathrm{C}$ for 5 days. Four 6 -mm-diameter agar disks were removed from the edge of actively growing cultures and placed into each of a series of 60-mm-diameter plastic petri dishes containing $7 \mathrm{ml}$ of a $1.5 \%$ nonsterile soil extract. Numerous sporangia formed after incubation of agar disks in darkness for $48 \mathrm{~h}$ at $24^{\circ} \mathrm{C}$. Sporangia were induced to release zoospores by chilling at $4^{\circ} \mathrm{C}$ for $20 \mathrm{~min}$. After rewarming at $25^{\circ} \mathrm{C}$ for $20 \mathrm{~min}$, the contents of each petri dish were decanted into a $250-\mathrm{ml}$ beaker through cheesecloth to remove agar disks and attached mycelia. One milliliter of the resultant zoospore suspension was added to the potting mix in each container 4 days after application of a test fungicide. After infestation of potting mix with zoospores of $P$. capsici, pepper plants were maintained in the greenhouse, watered as needed, and fertilized weekly with watersoluble Miracle Gro fertilizer (15-30-15; Stern's Miracle-Gro Products, Inc., Port Washington, NY) according to label rates. The mean temperature of the potting mix during these tests was $21^{\circ} \mathrm{C}$, with average 
low and high daily temperatures of 16 and $31^{\circ} \mathrm{C}$, respectively.

During the course of the study, the date was recorded when plants wilted permanently due to disease development. The experiment was terminated after approximately 3 months, when final disease severity was determined by measuring the fresh weights of pepper plant shoots and roots. Infection by $P$. capsici was confirmed by reisolating the pathogen from diseased plants. Four-month-old pepper plants were used for a second run of this experiment; otherwise, all other experimental conditions were similar to the first trial.

Before infestation of the potting mix, 0.1 $\mathrm{ml}$ of the zoospore suspension was added to $100 \mathrm{ml}$ of water and thoroughly mixed, after which a $0.5-\mathrm{ml}$ aliquot was distributed evenly over the agar surface within each of five 100-mm-diameter plastic petri dishes containing vancomycin-pimaricinpentachlornitrobenzene (PVP; 16) medium. These petri dishes, with lids removed, were maintained in a laminar-flow hood for $5 \mathrm{~min}$ to remove free moisture from the agar surface. Petri dishes then were incubated in darkness for $48 \mathrm{~h}$ at $24^{\circ} \mathrm{C}$, after which the number of fungal colonies developing from zoospores was determined. The number of zoospores applied to the potting mix for each pepper plant in the first and second run of this experiment was 2.0 and $2.8 \times 10^{4}$ zoospores/ml, respectively.

Disease development: naturally infested soil. Two-month-old chile pepper plants (cv. Anaheim TMR 23) were purchased from a commercial nursery for these studies. In September 1995, a clay loam soil from a field containing chile pepper plants with symptoms of root and crown rot was collected to a depth of 15 $\mathrm{cm}$ and thoroughly mixed. Plants within this field had not been treated with any fungicide prior to collection of soil. A chile pepper seedling was planted into a series of plastic pots $(10 \mathrm{~cm}$ in diameter by $10 \mathrm{~cm}$ deep) containing this naturally infested field soil. The soil in each container then was drenched with $300 \mathrm{ml}$ of a solution containing the same concentrations of test fungicides described above. Five replicate plants (one plant per pot) were treated with each concentration of each fungicide. Control plants were treated with water only. A control treatment consisting of noninfested soil was established by planting seedlings in field soil that had been heat-sterilized $\left(121^{\circ} \mathrm{C}, 102 \mathrm{kPa}, 60 \mathrm{~min}\right)$. Plants were maintained in the greenhouse and data collected as described above. The mean temperature of the soil during these tests was $20^{\circ} \mathrm{C}$, with average low and high daily temperatures of 15 and $29^{\circ} \mathrm{C}$, respectively.

Effect of soil moisture on fungicide efficacy. A clay loam soil from a field containing chile pepper plants with symptoms of root and crown rot was collected in September 1999, as described above, thoroughly mixed, then distributed into a series of plastic pots $(10 \mathrm{~cm}$ in diameter by $10 \mathrm{~cm}$ deep). This field had been treated once with mefenoxam prior to soil collection. A 2-month-old Anaheim TMR 23 pepper plant was planted in each pot, then the soil was drenched with $300 \mathrm{ml}$ of a solution containing azoxystrobin at $1,000 \mu \mathrm{g} / \mathrm{ml}$, dimethomorph at $100 \mu \mathrm{g} / \mathrm{ml}$, fosetyl-Al at $3,000 \mu \mathrm{g} / \mathrm{ml}$, fluazinam at $1,000 \mu \mathrm{g} / \mathrm{ml}$, or mefenoxam at $100 \mu \mathrm{g} / \mathrm{ml}$. Ten replicate plants (one plant per pot) were treated with each fungicide. Control plants were treated with water only. A noninfested control treatment was established by planting seedlings in field soil that had been heat sterilized as described earlier. For each treatment, five plants were watered as needed by wetting the entire soil profile within each pot (usually every 2 days) for the duration of the trial, whereas the other five plants were watered as needed except for a 48-h period every 2 weeks when the soil in each pot was flooded. Plants were maintained in the greenhouse and data collected as described earlier. The mean temperature of the soil in the pots during these tests was $20^{\circ} \mathrm{C}$, with average low and high daily temperatures of 9 and $30^{\circ} \mathrm{C}$, respectively.

Pepper stem and fruit inoculation. Two-month-old Anaheim TMR 23 chile pepper plants or mature green chile fruit (from AZ 20 plants) were used in these tests. In October 1999, a circular area of epidermis was removed from the stem of plants with a 5-mm-diameter cork borer, approximately $8 \mathrm{~cm}$ above the soil surface. Plants were inverted and the foliage and stem, including the wounded portion, were submerged for $2 \mathrm{~s}$ in a 2-liter aqueous solution of one of the following concentrations of fungicide: azoxystrobin at 600 $\mu \mathrm{g} / \mathrm{ml}$; dimethomorph at $480 \mu \mathrm{g} / \mathrm{ml}$; fluazinam at $1,200 \mu \mathrm{g} / \mathrm{ml}$; fosetyl-Al at $9,600 \mu \mathrm{g} / \mathrm{ml}$; maneb at $3,600 \mu \mathrm{g} / \mathrm{ml}$; or mefenoxam at $1,200 \mu \mathrm{g} / \mathrm{ml}$. Latron-B-1956 $(1.2 \mathrm{ml}$; Rohm and Haas, Co., Philadelphia), a nonionic surfactant used as a spreader-sticker, was added to each fungicide solution to improve coverage of plant surfaces. Concentrations of maneb and mefenoxam were derived from label rates of these compounds for pepper plants assuming application at a rate of 468.4 liters/ha. Concentrations of azoxystrobin, dimethomorph, fluazinam, and fosetyl-Al were used or being evaluated for control of Peronosproa parasitica and Bremia lactucae, oomycete pathogens that cause downy mildew on cole crops and lettuce, respectively $(12,13)$. After the plant surface was thoroughly dry, a 5-mm-diameter agar disk containing mycelium from an actively growing culture of $P$. capsici on V8A was placed onto the wound on each plant stem and secured in place with plastic tape. Plants then were placed in a series of large plastic bags, each of which contained a pan with a shallow layer of water to provide a humid environment favorable for infection. After incubation for $48 \mathrm{~h}$ at $28^{\circ} \mathrm{C}$ in the laboratory, plants were removed from the plastic bags and maintained for an additional 4 days at the same temperature. Disease severity was recorded by measuring the length of the canker that formed at the inoculation site.

A circular area of epidermis was removed from the middle of chile pepper fruit, treated with fungicides as described above, and allowed to dry. Chile fruit were placed in rectangular plastic boxes that contained two layers of moist paper towels on the bottom to maintain a high level of humidity. After inoculation at the wound site with an agar disk containing mycelium of Phytophthora capsici, lids were placed on the plastic boxes and fruit were incubated in the laboratory for 6 days at $28^{\circ} \mathrm{C}$. Disease severity was assessed by measuring the length of developing canker at the inoculation site.

Five replicate plants or fruit were treated with each concentration of each fungicide, whereas inoculated controls were treated with water only and noninoculated controls received an agar disk without mycelium. Removal of the epidermis on stem and fruit inoculation sites was performed to simulate plant damage that can occur during summer thunderstorms, when heavy rainfall, high gusty winds, and occasional hail can damage stems, leaves, and fruit at the same time that propagules of $P$. capsici are dispersed within and between pepper fields.

Recovery of $\boldsymbol{P}$. capsici from soil. Soil was collected from a chile pepper field infested with P. capsici in September 1999 and thoroughly mixed; next, $250 \mathrm{~cm}^{3}$ of this soil was dispensed into a series of plastic containers $\left(473 \mathrm{~cm}^{3}\right.$ in capacity) with drain holes. This field had been treated once with mefenoxam prior to soil collection. Five replicate soil samples were drenched with $300 \mathrm{ml}$ of a solution containing the same rate of each fungicide tested in the soil moisture study. Soil samples used as controls were drenched with water only. At 1 day after soil treatment, a mature but green, unblemished Bartlett pear fruit was placed on the surface of the soil in each container, and a 2-cm layer of water was maintained on the soil surface for $48 \mathrm{~h}$ in the greenhouse. This was accomplished by inserting the container with drain holes into a similar container without drain holes. After $48 \mathrm{~h}$ of incubation in water, pear fruit were removed from the soil, rinsed with tap water, and incubated for an additional 4 days in the greenhouse. The mean soil temperature during these tests was $23^{\circ} \mathrm{C}$, with average low and high daily temperatures of 19 and $31^{\circ} \mathrm{C}$, respectively. Firm brown spots developed on pear fruit infected with $P$. capsici. A small piece of tissue from each brown spot was placed onto PVP medium, incubated at $24^{\circ} \mathrm{C}$ in 
darkness, and observed for growth of $P$. capsici. The number of lesions caused by the pathogen was recorded.

Analysis of data. Each experiment in these investigations was conducted twice. Data from repeated experiments were combined for analysis, because variances between experiments were homogeneous. Data were processed with the SigmaStat statistical software package (SPSS Sci- ence, Chicago). Error bars in Figure 1 represent one-half of the $95 \%$ confidence intervals. Means with nonoverlapping $95 \%$ confidence intervals were considered significantly different (8).

\section{RESULTS}

Disease development: inoculation with zoospores. Plants survived longer and shoot and root fresh weights were greater for plants drenched with metalaxyl at 10 $\mu \mathrm{g} / \mathrm{ml}$ than for plants treated with the same rate of azoxystrobin or dimethomorph (Fig. 1). At $100 \mu \mathrm{g} / \mathrm{ml}$, the duration of plant survival was greater for dimethomorph and fluazinam than for azoxystrobin; however, shoot and root growth did not differ. At a concentration of $1,000 \mu \mathrm{g} / \mathrm{ml}$, the duration of survival after inoculation was greater with dimethomorph, fluazinam, and fose-

\section{Potting mix infested with zoospores}
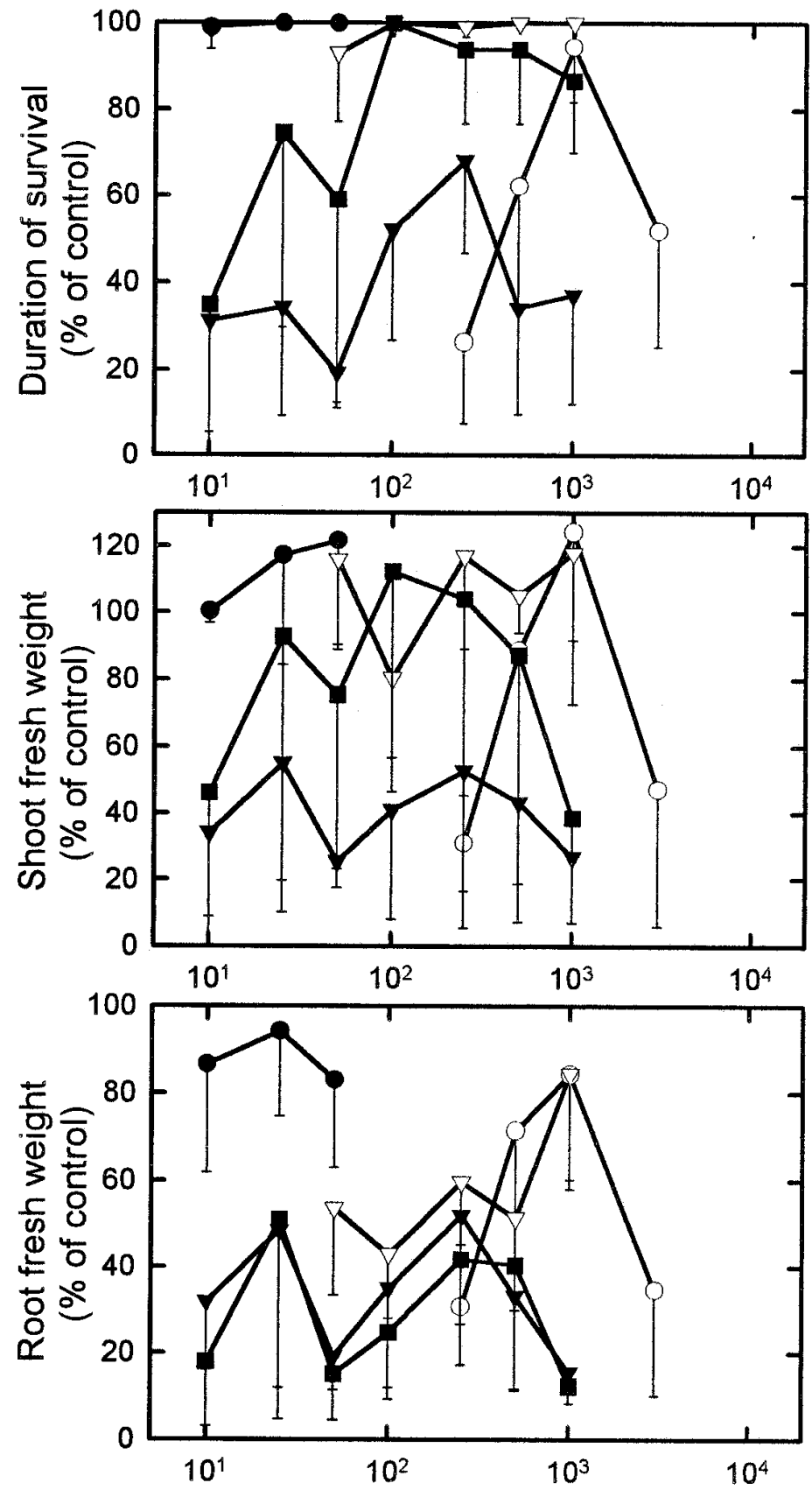

Naturally infested soil
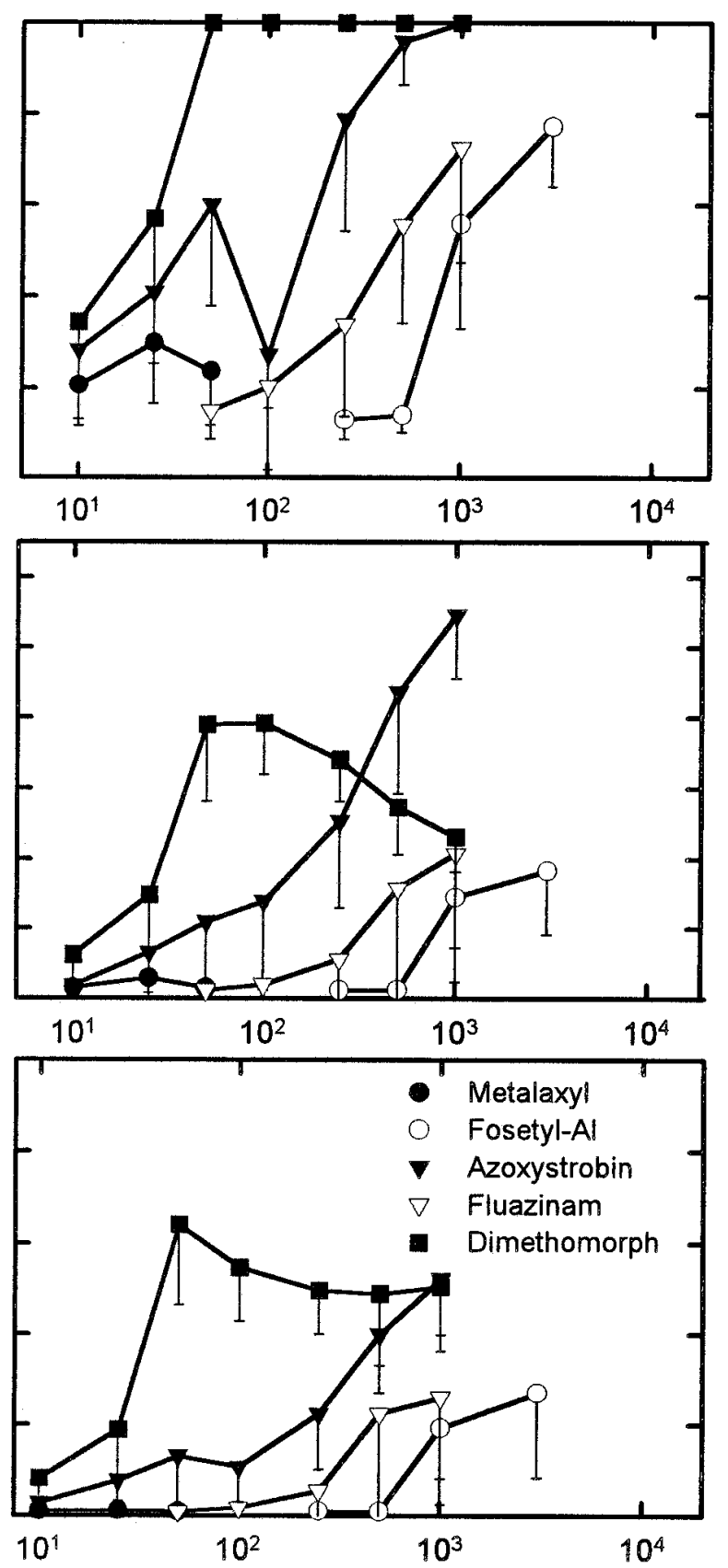

Fungicide concentration ( $\mu \mathrm{g}$ a.i. $/ \mathrm{ml}$ )

Fig. 1. The duration of plant survival as well as shoot and root fresh weight for chili pepper plants grown either in potting mix infested with zoospores of Phytophthora capsici or in soil naturally infested with the pathogen, as a percent of these values for noninfected control plants, after a single treatment with azoxystrobin, dimethomorph, fluazinam, fosetyl-Al, or metalaxyl. Each value is the mean of 10 replicate plants. Error bars represent one-half of the $95 \%$ confidence intervals. 
tyl-Al than with azoxystrobin; shoot and root fresh weight was greater with fluazinam and fosetyl-Al than with azoxystrobin and dimethomorph (Fig. 1). Phytotoxicity, necrotic leaf spots, and reduced shoot and root growth was evident on plants exposed to dimethomorph at rates of 250,500 and $1,000 \mu \mathrm{g} / \mathrm{ml}$.

Disease development: naturally infested soil. Plant survival and shoot and root fresh weight were similar for azoxystrobin, dimethomorph, or metalaxyl at 10 $\mu \mathrm{g} / \mathrm{ml}$ (Fig 1). At $100 \mu \mathrm{g} / \mathrm{ml}$, survival and growth of shoots and roots for plants treated with dimethomorph were greater than for those treated with azoxystrobin and fluazinam. At a concentration of 1,000 $\mu \mathrm{g} / \mathrm{ml}$, survival was higher with azoxystrobin and dimethomorph compared to fluazinam and fosetyl-Al, whereas shoot weight for azoxystrobin was greater than for dimethomorph, fluazinam, and fosetyl$\mathrm{Al}$; root fresh weight did not differ significantly among the four compounds (Fig. 1).
Phytotoxicity in addition to reduced shoot and root growth, as described earlier for plants grown in potting mix, was evident on plants grown in field soil treated with dimethomorph at rates of 250,500 , and $1,000 \mu \mathrm{g} / \mathrm{ml}$.

Effect of soil moisture on fungicide efficacy. For plants grown in field soil naturally infested with $P$. capsici and subjected to a 48-h flood period every 2 weeks, the duration of survival and shoot and root fresh weight were greater for plants that received one treatment of dimethomorph at $100 \mu \mathrm{g} / \mathrm{ml}$ or fluazinam at $1,000 \mu \mathrm{g} / \mathrm{ml}$ than plants treated once with azoxystrobin at $1,000 \mu \mathrm{g} / \mathrm{ml}$ or fosetyl-Al at $3,000 \mu \mathrm{g} / \mathrm{ml}$ (Table 1). Plant survival and root fresh weight values for chile pepper plants grown in soil treated with mefenoxam at $100 \mu \mathrm{g} / \mathrm{ml}$ were significantly greater than that recorded in soil treated with fosetyl-Al at $3,000 \mu \mathrm{g} / \mathrm{ml}$ and significantly less than that recorded in soil treated with dimethomorph at $100 \mu \mathrm{g} / \mathrm{ml}$. On the other

Table 1. Effect of fungicides applied to soil on plant survival and root and shoot weight under two soil moisture regimes for chili pepper plants grown in soil naturally infested with Phytophthora capsici $^{\mathrm{y}}$

\begin{tabular}{llccc}
\hline & & \multicolumn{2}{c}{ Fresh weight $(\mathrm{g})$} \\
\cline { 5 - 5 } Treatment & Duration of plant survival (days) & Shoot & Root \\
\hline Plants flooded for $48 \mathrm{~h}$ every 2 weeks & & & \\
Sterilized soil & & & & \\
Dimethomorph at $100 \mu \mathrm{g} / \mathrm{ml}$ & $62.0 \mathrm{f}$ & $18.2 \mathrm{~g}$ & $22.4 \mathrm{i}$ \\
Fluazinam at $1,000 \mu \mathrm{g} / \mathrm{ml}$ & $52.0 \mathrm{f}$ & $13.6 \mathrm{c}-\mathrm{f}$ & $19.0 \mathrm{hi}$ \\
Mefenoxam at $100 \mu \mathrm{g} / \mathrm{ml}$ & $58.8 \mathrm{ef}$ & $14.3 \mathrm{e}-\mathrm{g}$ & $18.9 \mathrm{hi}$ \\
Azoxystrobin at $1,000 \mu \mathrm{g} / \mathrm{ml}$ & $49.8 \mathrm{c}-\mathrm{e}$ & $9.6 \mathrm{bc}$ & $13.5 \mathrm{fg}$ \\
Fosetyl-Al at $3,000 \mu \mathrm{g} / \mathrm{ml}$ & $45.3 \mathrm{c}$ & $7.7 \mathrm{~b}$ & $8.5 \mathrm{c}-\mathrm{e}$ \\
Nonsterilized soil & $27.2 \mathrm{~b}$ & $3.3 \mathrm{a}$ & $6.4 \mathrm{a}-\mathrm{c}$ \\
Plants watered as needed & $9.2 \mathrm{a}$ & $1.4 \mathrm{a}$ & $3.4 \mathrm{ab}$ \\
Sterilized soil & & & \\
Dimethomorph at $100 \mu \mathrm{g} / \mathrm{ml}$ & $62.0 \mathrm{f}$ & $17.5 \mathrm{fg}$ & $15.4 \mathrm{gh}$ \\
Mefenoxam at $100 \mu \mathrm{g} / \mathrm{ml}$ & $62.0 \mathrm{f}$ & $15.1 \mathrm{fg}$ & $10.5 \mathrm{c}-\mathrm{f}$ \\
Fluazinam at $1,000 \mu \mathrm{g} / \mathrm{ml}$ & $58.7 \mathrm{ef}$ & $13.9 \mathrm{~d}-\mathrm{f}$ & $11.3 \mathrm{~d}-\mathrm{g}$ \\
Azoxystrobin at $1,000 \mu \mathrm{g} / \mathrm{ml}$ & $56.9 \mathrm{def}$ & $14.3 \mathrm{~d}-\mathrm{g}$ & $11.8 \mathrm{e}-\mathrm{g}$ \\
Fosetyl-Al at $3,000 \mu \mathrm{g} / \mathrm{ml}$ & $49.3 \mathrm{~cd}$ & $10 \mathrm{~b}-\mathrm{e}$ & $7.5 \mathrm{~b}-\mathrm{d}$ \\
Nonsterilized soil & $47.8 \mathrm{~cd}$ & $10.2 \mathrm{~b}-\mathrm{d}$ & $7.5 \mathrm{~b}-\mathrm{d}$ \\
LSD $(P=0.05)$ & $16.4 \mathrm{a}$ & $2.2 \mathrm{a}$ & $3.1 \mathrm{a}$ \\
\hline
\end{tabular}

${ }^{y}$ Each value is the mean of 10 replicate plants. Numbers in each column followed by a different letter are significantly different $(P=0.05)$ according to the Duncan-Waller $k$-ratio least significant difference (LSD) test.

${ }^{\mathrm{z}}$ Each value represents the average elapsed time in days from initiation of the experiment to death of plants. Plants were considered dead when leaves wilted permanently. Fungicide treatments were applied to soil on the same day that peppers were transplanted.

Table 2. Development of lesions on stems and fruit of chili peppers inoculated with Phytophthora capsici after application of fungicides

\begin{tabular}{lcc}
\hline & \multicolumn{2}{c}{${\text { Length of lesion }(\mathbf{m m})^{\mathbf{z}}}$} \\
\cline { 2 - 3 } Treatment & Stem & Fruit \\
\hline Noninoculated control & $0 \mathrm{a}$ & $0 \mathrm{a}$ \\
Mefenoxam at $1,200 \mu \mathrm{g} / \mathrm{ml}$ & $2 \mathrm{a}$ & $0 \mathrm{a}$ \\
Fosetyl-Al at $9,600 \mu \mathrm{g} / \mathrm{ml}$ & $4 \mathrm{a}$ & $50 \mathrm{~b}$ \\
Dimethomorph at $480 \mu \mathrm{g} / \mathrm{ml}$ & $22 \mathrm{ab}$ & $4 \mathrm{a}$ \\
Azoxystrobin at $600 \mu \mathrm{g} / \mathrm{ml}$ & $38 \mathrm{~b}$ & $81 \mathrm{c}$ \\
Maneb at $3,600 \mu \mathrm{g} / \mathrm{ml}$ & $89 \mathrm{c}$ & $92 \mathrm{c}$ \\
Fluazinam at $1,200 \mu \mathrm{g} / \mathrm{ml}$ & $90 \mathrm{c}$ & $87 \mathrm{c}$ \\
Inoculated control & $90 \mathrm{c}$ & $88 \mathrm{c}$ \\
LSD $(P=0.05)$ & 25 & 17 \\
\hline
\end{tabular}

${ }^{\mathrm{z}}$ Each value is the mean of 10 replicate plants or pepper fruit. Numbers in each column followed by a different letter are significantly different $(P=0.05)$ according to the Duncan-Waller $k$-ratio least significant difference (LSD) test.

hand, shoot fresh weight for plants treated with dimethomorph or mefenoxam were not different from each other, but both were greater than fosetyl-Al.

When plants were grown in field soil naturally infested with $P$. capsici and watered only as needed, the duration of survival and shoot and root fresh weight were not different between soil treated with dimethomorph at $100 \mu \mathrm{g} / \mathrm{ml}$, fluazinam at $1,000 \mu \mathrm{g} / \mathrm{ml}$, or mefenoxam at $100 \mu \mathrm{g} / \mathrm{ml}$ (Table 1). Plant survival and shoot fresh weight values for all three of these fungicides did not differ significantly from those recorded for chile peppers grown in sterilized field soil.

Pepper stem and fruit inoculation. The most effective chemicals for inhibiting the development of lesions on chile pepper plant stems and fruit inoculated with $P$. capsici were mefenoxam at $1,200 \mu \mathrm{g} / \mathrm{ml}$ and dimethomorph at $480 \mu \mathrm{g} / \mathrm{ml}$ (Table 2). Fosetyl-Al at $9,600 \mu \mathrm{g} / \mathrm{ml}$ was equally effective in inhibiting development of lesions on plant stems but less efficacious on pepper fruit. Lesion growth on inoculated stems and fruit treated with fluazinam at $1,200 \mu \mathrm{g} / \mathrm{ml}$ or maneb at $3,600 \mu \mathrm{g} / \mathrm{ml}$ was not significantly different than that recorded on plants and fruit not treated with a fungicide.

Recovery of $\boldsymbol{P}$. capsici from soil. No lesions developed on pear fruit incubated with soil containing $P$. capsici and treated with azoxystrobin at $1,000 \mu \mathrm{g} / \mathrm{ml}$, dimethomorph at $100 \mu \mathrm{g} / \mathrm{ml}$, or fluazinam at $1,000 \mu \mathrm{g} / \mathrm{ml}$ (Table 3). A few lesions developed on fruit incubated in soil treated with fosetyl-Al at $3,000 \mu \mathrm{g} / \mathrm{ml}$ or mefenoxam at $100 \mu \mathrm{g} / \mathrm{ml}$. Recovery of $P$. capsici from soil treated with each of the five tested compounds was significantly less than that recorded for soil not receiving a fungicide.

\section{DISCUSSION}

The efficacy of the fungicides examined differed in their activity against root and

Table 3. Development of lesions on pear fruit incubated with field soil containing Phytophthora capsici and drenched with a fungicide

\begin{tabular}{lc}
\hline Treatment & $\begin{array}{c}\text { No. of lesions } \\
\text { on pear fruit }\end{array}$ \\
\hline Azoxystrobin at $1,000 \mu \mathrm{g} / \mathrm{ml}$ & $0 \mathrm{a}$ \\
Dimethomorph at $100 \mu \mathrm{g} / \mathrm{ml}$ & $0 \mathrm{a}$ \\
Fluazinam at $1,000 \mu \mathrm{g} / \mathrm{ml}$ & $0 \mathrm{a}$ \\
Fosetyl-Al at $3,000 \mu \mathrm{g} / \mathrm{ml}$ & $0.3 \mathrm{a}$ \\
Mefenoxam at $100 \mu \mathrm{g} / \mathrm{ml}$ & $0.6 \mathrm{a}$ \\
Nontreated soil & $33.9 \mathrm{~b}$ \\
LSD $(P=0.05)$ & 5.7 \\
\hline
\end{tabular}

${ }^{\mathrm{z}}$ Each value is the mean of 10 replicate soil samples. Lesion development was confirmed as resulting from colonization by $P$. capsici by reisolating the pathogen from test fruit. Numbers in each column followed by a different letter are significantly different $(P=0.05)$ according to the Duncan-Waller $k$-ratio least significant difference (LSD) test. 
crown rot compared to activity on stem and fruit lesion development caused by $P$. capsici. For example, at an appropriate concentration, azoxystrobin, dimethomorph, fosetyl-Al, fluazinam, mefenoxam, or metalaxyl significantly improved chile pepper growth and survival in potting mix or soil containing $P$. capsici compared to plants not receiving a fungicide. On the other hand, fluazinam did not significantly reduce lesions on inoculated pepper plant stems. Likewise, lesion growth on pepper fruit inoculated with $P$. capsici after treatment with azoxystrobin or fluazinam did not differ from that on nontreated fruit. One factor that may partially account for these differences is that the level of resistance to the root and crown rot phase of Phytophthora blight in pepper plants can differ from the resistance to the foliar phase (19). Also, there may be differences in uptake of each fungicide by roots compared to stems or fruit. Perhaps such differences in uptake and in the inherent genetic resistance or susceptibility to the two phases of the disease could partially account for the differential activity of some tested chemistries on the root and crown rot phase compared to the foliar component of Phytophthora blight on chile pepper.

The apparent efficacy of tested fungicides against the development of root and crown rot appeared to be affected by the pathogen propagule or propagules that served as inoculum. In these studies, the relative efficacy of a compound when zoospores of $P$. capsici were introduced into potting mix could differ from the performance of the fungicide in soil naturally infested with the pathogen. In general, tested fungicides appeared to perform better in potting mix infested with zoospores of $P$. capsici than in field soil naturally infested with the pathogen. A partial explanation could be the existence of several different propagules of $P$. capsici in field soil, such as oospores, mycelial fragments, and sporangia, in addition to zoospores (2). Also, plants growing in naturally infested field soil would be subject to repeated exposure to zoospores, unlike the single exposure when zoospores were used as inoculum. Earlier studies have demonstrated that mycelial growth, sporangium formation, zoospore motility, and zoospore cyst germination are differentially affected by azoxystrobin, dimethomorph, fosetyl-Al, fluazinam, and metalaxyl (14).

Mefenoxam is registered in the United States for management of Phytophthora blight on pepper. When subjected to periodic soil saturation, which favors rapid development of root and crown rot, plant growth and survival in field soil naturally infested with $P$. capsici was lower for plants treated once with mefenoxam at 100 $\mu \mathrm{g} / \mathrm{ml}$ compared to those grown in sterilized soil. On the other hand, chile pepper plant growth and survival in infested soil treated once with mefenoxam and watered as needed were not different from plants grown in sterilized field soil.

Mefenoxam also provided excellent protection against development of stem and fruit lesions. Mefenoxam was widely used for the first time in 1997 in pepper fields in North Carolina and New Jersey, followed by the detection of resistance to this chemistry in $57 \%$ of tested field isolates of $P$. capsici in these states $(18,19)$. The greatest number of isolates resistant to mefenoxam was recovered from fields where this compound was used exclusively rather than in combination or alternation with other fungicides (19). Clearly, there is an urgent need for efficacious fungicides in addition to mefenoxam to prevent disease control failure in treated pepper fields subjected to high disease pressure during prolonged periods of plant wetness and saturated soil conditions, and to minimize the development of resistance to this chemistry by $P$. capsici.

Initial disease development occurs on pepper plants when the primary inoculum of $P$. capsici in the soil initiates root infections that progress to crown infections (20). Wilting usually precedes development of crown rot in naturally infested soil (20) and signals that plant death is imminent. At an appropriate concentration, a single soil application of azoxystrobin, dimethomorph, fosetyl-Al, and fluazinam, in addition to mefenoxam, significantly prolonged the life of chile pepper plants growing in field soil naturally infested with $P$. capsici compared to plants not receiving a fungicide treatment. Of these four tested alternative fungicides, dimethomorph at a rate of $100 \mu \mathrm{g} / \mathrm{ml}$ was among the best materials with respect to minimizing plant death and loss of shoot and root mass.

A soil treatment with fosetyl-Al was the least effective of tested fungicides in inhibiting root and crown rot development. The relative effectiveness of azoxystrobin and fluazinam on plant survival and growth in infested field soil generally ranged between those levels recorded for dimethomorph and fosetyl-Al. Earlier research demonstrated the necessity of multiple applications of fosetyl-Al to reduce the level of root rot in potted tomato plants inoculated with zoospores of $P$. parasitica (4). Perhaps multiple applications of compounds examined in these studies would improve the final degree of disease control for chile pepper plants as well.

Previous research with the five fungicides examined in these studies revealed that mycelial growth of $P$. capsici and two additional Phytophthora spp. on corn meal agar was most sensitive to dimethomorph, intermediate in sensitivity to fosetyl-Al and metalaxyl, and least sensitive to azoxystrobin and fluazinam (14). Fungicide performance as measured by inhibition of lesion formation on pepper stems and fruit treated with these compounds and inoculated with mycelium of $P$. capsici generally are in agreement with these earlier in vitro studies. The same research (14) revealed that azoxystrobin, dimethomorph, fosetylAl, fluazinam, and metalaxyl had a greater impact on sporangium formation than on inhibition of mycelial growth, suggesting that our studies measuring inhibition of mycelial growth may underestimate the potential utility of these compounds in managing the foliar phase of Phytophthora blight, which in the field is initiated and sustained by successive cycles of sporangium formation and zoospore release (19). Indeed, previous studies have demonstrated the effectiveness of dimethomorph $(3,6)$ and fluazinam $(5)$ against late blight in potato caused by $P$. infestans. Additionally, azoxystrobin, dimethomorph, and fosetyl-Al provided significant control against downy mildew on broccoli (12) and lettuce (13) caused by the oomycete pathogens Peronospora parasitica and Bremia lactucae, respectively.

The comparative efficacy of azoxystrobin, dimethomorph, fosetyl-Al, and fluazinam as potential chemical management tools for Phytophthora blight on chile pepper plants has been demonstrated. The future availability of one or more of these fungicides would allow fungicide treatment with chemical compounds possessing different modes of action, a development that could prolong the effectiveness of these materials for disease management. However, successful sustainable management of Phytophthora blight in chile pepper will require the implementation of a multifaceted disease management system as outlined by Ristaino and Johnston (19), with chemical control as but one component.

\section{LITERATURE CITED}

1. Bosland, P. W., and Lindsey, D. L. 1991. A seedling screen for Phytophthora root rot of pepper, Capsicum annuum. Plant Dis. 75:1048-1050.

2. Bowers, J. H., Papavizas, G. C., and Johnston, S. A. 1990. Effect of soil temperature and soil-water matric potential on the survival of Phytophthora capsici in natural soil. Plant Dis. 74:771-777.

3. Cohen, Y., Baider, A., and Cohen, B. H. 1995. Dimethomorph activity against oomycete fungal plant pathogens. Phytopathology 85:1500-1506.

4. Davis, R. M. 1989. Effectiveness of fosetylAl against Phytophthora parasitica on tomato. Plant Dis. 73:215-217.

5. Dowley, L. J., and O'Sullivan, E. 1995. Activity of fluazinam against late blight of potatoes. Irish J. Agric. Food Res. 34:33-37.

6. Dowley, L. J., and O'Sullivan, E. 1996. The effect of dimethomorph on the control of late blight of potatoes. Irish J. Agric. Food Res. 35:165-169.

7. Gisi, U., Hermann, D., Ohl, L., and Steden, C. 1997. Sensitivity profiles of Mycosphaerella graminicola and Phytophthora infestans populations to different classes of fungicides. Pestic. Sci. 51:290-298.

8. Glantz, S. A. 1992. Primer of Biostatistics, 3rd ed. McGraw-Hill Book Co., New York.

9. Johnston, S. A., 1990. Control of Phytophthora blight of peppers by injection of 
metalaxyl through drip irrigation. (Abstr.) Phytopathology 80:120.

10. Marks, G. C., and Smith, I. W. 1990. Control of experimental Phytophthora cinnamomi stem infections of Rhododendron, Leucadendron, and Eucalyptus by dimethomorph, fosetyl-Al and metalaxyl. Aust. J. Exp. Agric. 30:139-143

11. Matheron, M. E., and Matejka, J. C. 1995. Comparative activities of sodium tetrathiocarbonate and metalaxyl on Phytophthora capsici and root and crown rot on chile pepper. Plant Dis. 79:56-59.

12. Matheron, M. E., and Porchas, M. 1996. Comparison of several fungicides for control of downy mildew on broccoli. (Abstr.). Phytopathology 86:S4.

13. Matheron, M. E., and Porchas, M. 1998. Comparative evaluation of chemical management tools for downy and powdery mildew of lettuce. (Abstr.) Phytopathology 88:S59.

14. Matheron, M. E., and Porchas, M. 2000. Impact of azoxystrobin, dimethomorph, fluazinam, fosetyl-Al, and metalaxyl on growth, sporulation, and zoospore cyst germination of three Phytophthora spp. Plant Dis. 84:454-458.

15. Matheron, M. E., Porchas, M., and Matejka, J. C. 1997. Distribution and seasonal population dynamics of Phytophthora citrophthora and $P$. parasitica in Arizona citrus orchards and effects of fungicides on tree health. Plant Dis. 81:1384-1390.

16. Mircetich, S. M., and Matheron, M. E. 1976. Phytophthora root and crown rot of cherry trees. Phytopathology 66:549-558.

17. Papavizas, G. C., and Bowers, J. H. 1981. Comparative fungitoxicity of captafol and metalaxyl to Phytophthora capsici. Phytopathology 71:123-128.

18. Parra, G., and Ristaino, J. 1998. Insensitivity to Ridomil Gold (mefenoxam) found among field isolates of Phytophthora capsici causing Phytophthora blight on bell pepper in North Carolina and New Jersey. Plant Dis. 82:711.

19. Ristaino, J. B., and Johnston, S. A. 1999. Ecologically based approaches to management of Phytophthora blight on bell pepper. Plant Dis. 83:1080-1089.
20. Ristaino, J. B., Larkin, R. P., and Campbell, C. L. 1994. Spatial dynamics of disease symptom expression during Phytophthora epidemics on bell pepper. Phytopathology 84:1015-1024.

21. Simons, J. N., Simons, J. E., and Winsberg, T. 1991. Control of Phytophthora crown rot in bell pepper with directed sprays of metalaxyl. Proc. Annu. Meet. Fla. State Hortic. Soc. 103:120-121.

22. Sung, N. K., and Hwang, B. K. 1988. Comparative efficacy and in vitro activity of metalaxyl and metalaxyl-copper oxychloride mixture for control of Phytophthora blight of pepper plants. Korean J. Pathol. 4:185-196.

23. Timmer, L. W., and Castle, W. S. 1985. Effectiveness of metalaxyl and fosetyl Al against Phytophthora parasitica on sweet orange. Plant Dis. 69:741-743.

24. Washington, W. S., Shanmuganathan, N., and Forbes, C. 1992. Fungicide control of strawberry fruit rots, and the field occurrence of resistance of Botrytis cinerea to iprodione, benomyl and dichlofluanid. Crop Prot 11:355-360. 